\title{
KEPEMIMPINAN KEPALA TAMAN KANAK-KANAK DI PERSEKOLAHAN KANISIUS
} YOGYAYAKARTA

\author{
Lusila Parida, Wiwik Wijayanti \\ STKIP Persada Khatulistiwa Sintang, Universitas Negeri Yogyakarta \\ lusila.parida@yahoo.co.id,wiwikashari@gmail.com
}

\begin{abstract}
Abstrak
Tujuan penelitian ini adalah untuk mendeskripsikan kemampuan kepala TK dalam: (1) mengarahkan guru dan staf, (2) membuat keputusan penting (3) memberikan pendelegasian tugas dan, (4) membangun hubungan kerja sama secara internal dan eksternal. Penelitian ini menggunakan pendekatan kualitatif dengan jenis studi kasus pada tiga sekolah TK Kanisius Yogyakarta. Subjek penelitian yaitu kepala sekolah, guru, orang tua siswa (komite sekolah). Teknik pengumpulan data menggunakan teknik observasi dan wawancara. Analisis data yang digunakan adalah model analisis interaktif Milles \& Huberman untuk mendeskripsikan dan menganalisis empat aspek kepemimpinan yang dijalankan pada ketiga sekolah tersebut. Penelitian ini menemukan pelaksanaan kepemimpinan kepala TK Kanisius: (1) pengarahan dilakukan secara langsung dan tidak langsung melalui rapat, diskusi dan morning briefing mengenai tugas pokok, tugas khusus dan tugas penunjang, (2) proses pengambilan keputusan melalui musyawarah dengan koordinasi pihak yayasan (3) pendelegasian tugas pokok, tugas khusus dan tugas penunjang yang didasarkan pada kemampuan bawahan, durasi waktu, jenis tugas dan target pencapaian, (4) kerja sama internal dan eksternal dibangun melalui team dan mitra bersama komite sekolah yang digerakan atau disponsori oleh team orang tua. Berdasarkan temuan tersebut maka perilaku kepemimpinan kepala TK Kanisus Demangan Baru berorientasi pada perilaku supportif, perilaku kepemimpinan kepala TK Kanisius Kotabaru berorientasi pada perilaku direktif dan perilaku kepemimpinan kepala TK Kanisius Wirobrajan berorientasi pada perilaku partisipatif. Dari temuan perilaku kepemimpinan tersebut maka model kepemimpian yang diperankan ketiga kepala TK Kanisus cenderung menunjukan model kepemimpinan instruksional.
\end{abstract}

Kata kunci: kepemimpinan kepala TK, perilaku kepemimpinan dan model kepemimpinan

\section{PRINCIPALS' LEADERSHIP IN CANISIUS KINDERGARTENS YOGYAKARTA}

\author{
Lusila Parida, Wiwik Wijayanti \\ STKIP Persada Khatulistiwa Sintang, Universitas Negeri Yogyakarta \\ lusila.parida@yahoo.co.id, wiwikashari@gmail.com
}

\begin{abstract}
This research aims to describe the ability of the head of kindergarten in: (1) directing teachers and staff, (2) making important decisions (3) provide the delegation of tasks and, (4) establish working relationships both internally and externally. This study uses a qualitative approach with case studies on three kindergarten Canisius Yogyakarta. The research subject is the principal, teachers, parents students (school committee). Data collection technique used observation and interview techniques. Analysis of the data used is an interactive model Milles \& Huberman to describe and analyze four aspects of leadership that run on all three schools. This study found the implementation of leadership in TK Canisius: (1) directly or indirectly through meetings, discussions, and briefings on main tasks, special tasks and supporting duties, (2) decision making process in compliace the board of foundation (3) task delegation that suits on the capacity of each subordinates, project timeline and target,(4) internal and external cooperation built through fundamental activities, special activities and support activities as well as maintaining relationships both personally and socially. Based on these findings, the behavior of the leadership of the head of Kanisus Demangan Baru kindergarten oriented supportive behavior, the behavior of the leadership of the head of Canisius Kotabaru kindergarten oriented directive behavior and leadership behavior Canisius head Wirobrajan kindergarten oriented participative behavior. From the findings of the leadership behavior of the model of leadership, played three head of Canisus kindergartens more trend on instructional leadership model.
\end{abstract}

Keywords: kindergarten leadership, leadership behaviors and leadership models 


\section{Pendahuluan}

Kepala sekolah adalah tokoh sentral dalam peningkatan mutu, relevansi dan daya saing pendidikan. Peran kepala sekolah sangat strategis dalam upaya mewujudkan sekolah yang bermutu dan memiliki daya saing global sesui arah dan citacita pendidikan menuju insan Indonesia yang cerdas dan kompetitif. Kepala sekolah sebagai pimpinan diharapkan mampu menjadi penyumbang keberhasilan bagi penguatan mutu tata kelola, akuntabilitas dan pencitraan publik pendidikan Indonesia. Harapan ini jelas disuarakan dalam Peraturan Pemerintah Nomor 28 Tahun 2010 tentang Penugasan Guru sebagai Kepala Sekolah, pada bab pendahuluan pasal 1 ayat (5) yang mewajibkan seorang kepala sekolah harus memiliki "kompetensi pengetahuan, sikap dan keterampilan pada dimensi-dimensi kompetensi baik kepribadian, manajerial, kewirausahaan, supervisi, dan sosial."

Peningkatan mutu pendidikan menjadi tujuan nasional namun tidak semua institusi dan pelaku pendidikan dapat mewujudkannya dengan mudah dan cepat sesuai rekomendasi konstitusional melalui peraturan pemerintah dan undang undang sisdiknas. Kepala sekolah professional harus mampu melayani dan memuaskan semua pihak baik siswa, orang tua, masyarakat luas, pemerintah pusat, pemerintah daerah, dinas pendidikan, maupun dunia usaha atau industri yang bakal menerima out put sekolah. Peran penting kepemimpinan menjadi hal yang patut diperhatikan dan diberdayakan dalam proses mencapai mutu pendidikan saat ini.

Salah satu sekolah atau Yayasan pendidikan yang sudah sangat familiar bagi masyarakat Yogyakarta dan Jawa Tengah pada umumnya adalah sekolah-sekolah Kanisius. Yayasan Kanisius memiliki sekolah dari jenjang TK sampai SMU dan tersebar di wilayah Provinsi Jawa Tengah. Sekolah Kanisius telah bereksistensi jauh sebelum Indonesia Merdeka. Tepatnya tahun 1918 Yayasan atau sekolah Kanisius berdiri dengan prioritas orientasi visi pendidikan ketika itu yakni melayani pendi- dikan bagi masyarakat yang terpinggirkan atau kaum "wong cilik". Dengan demikian jika kita menghitung usia Yayasan dan persekolah Kanisius usianya hampir satu abad (100 tahun pada tahun 2018). Sebuah pembuktian bahwa sekolah Kanisius bukan sekolah gampangan karena sudah teruji hampir satu abad dan masih tetap bereksistensi sampai saat ini. Inilah fenomena menarik yang perlu dikaji termasuk dari sudut pandang kepemimpinan pendidikan pada yayasan dan persekolahan Kanisius. Tentu dimensi kepimpinan pendidikan ikut memiliki andil dalam melestarikan dan mengembangkan pendidikan di yayasan dan Persekolahan Kanisius. Persekolahan Kanisius dahulu menjadi "voorloper" pelopor, perintis, pendahulu atau pembuka dalam banyak kegiatan parochial Gereja namun sekarang tinggal menjadi kegiatan segmentarian, baik secara kemasyarakatan luas maupun dalam konteks Gerejani (Maryono, 1993, p. 121).

TK Kanisius saat ini mengalami grafik penurunan baik dari sisi jumlah sekolah maupun jumlah penerimaan siswa. Beberapa sekolah diwilayah tertentu cukup stabil dan mampu bertahan tetapi di beberapa wilayah mengalami penurunan. TK Kanisius Kotabaru misalnya, secara statistik pada jangka waktu lima tahun terakhir mengalami penurunan jumlah siswa. Rata-rata pertahun jumlah siswa tidak mencapai 35 siswa. Jumlah siswa pada tahun ajaran 2012/ 2013 sebanyak 32 siswa, tahun ajaran 2013/ 2014 sebanyak 29 siswa, tahun ajaran 2015/ 2016 sebanyak 23 siswauntuk dua kelas pararel. Menurunnya jumlah siswa tersebut dapat dibuktikan dengan data perbandingan jumlah siswa periode tahun 1990-1993 dan tahun 2013-2015 pada Tabel 1.

Penurunan jumlah siswa seperti pada grafik tersebut, tentu menantang aspek kepemimpinan kepala sekolah dalam mengarahkan guru dan karyawan, mengambil keputusan, pendelegasian dan pengembangan hubungan kerja sama internal dan eksternal, untuk membangun visi sekolah yang bermutu dan memiliki daya saing dengan tetap mempertahankan identitas sekolah Katolik. 
Tabel 1. Data Perbandingan Siswa TK Kanisius Yogyakarta

\begin{tabular}{llll}
\hline $\begin{array}{l}\text { Tahun } \\
\text { Ajaran }\end{array}$ & TK DB & $\begin{array}{l}\text { TK } \\
\text { KB }\end{array}$ & $\begin{array}{l}\text { TK } \\
\text { WB }\end{array}$ \\
\hline 1991 & 107 & 80 & 90 \\
1992 & 117 & 85 & 105 \\
1993 & 119 & 90 & 116 \\
\hline Jumlah & 343 & 225 & 311 \\
\hline 2013 & 115 & 32 & 81 \\
2014 & 110 & 29 & 80 \\
2015 & 96 & 23 & 81 \\
Jumlah & 321 & 84 & 242 \\
\hline
\end{tabular}

(Sumber: Maryono, 1993, p. 82 \& Data

Statistik TK Kanisus Yogyakarta)

Koontz (Wahjosumidjo, 2013, p. 105) menguraikan bahwa kepala sekolah sebagai seorang pemimpin harus mampu mendorong timbulnya kemauan yang kuat dengan penuh semangat dan percaya diri pada guru, staf dan siswa dalam melaksanakan tugas masing-masing. Kepala sekolah memiliki kewajiban untuk memberikan bimbingan, dorongan dan mengarahkan para guru, staf dan para siswa. Sebagai pemimpin Ia memacu dan berdiri didepan demi kemajuan. Memberikan inspirasi dalam mencapai tujuan sekolah. Tujuan sekolah dapat terwujud jika kepala sekolah sungguh-sungguh hadir sebagai pemimpin. Keberhasilan kepala sekolah dalam aspek kepemimpinan sekolah ditentukan oleh tiga elemen. Zbar, Marshall \& Power (2007, p. 5) menjelaskan bahwa tiga elemen sebagai kunci dalam meningkatkan performance kinerja sekolah adalah design, perseption and capacity. Elemen design berhubungan dengan kemampuan kepala sekolah dalam membangun struktur regulasi sekolah, menyusun rencana pengembangan sekolah, membuat uraian tugas atau job descriptiondan melakukan penataan administrasi sekolah yang baik. Elemen perseption, berhubungan dengan kemampuan kepala sekolah dalam membangun komunikasi, memberikan motivasi dan mengembangkan kolegalitas. Elemen capacity, berhubungan dengan kemampuan kepala sekolah dalam mengembangan efektivitas guru, mengembangkan iklim kelas serta melakukan pengamatan, pengawasan dan penilaian belajar. Peran dan fungsi kepala sekolah juga sebagai manajer dengan rencana strategis yang tepat dalam memberdayakan segala sumber daya sekolah untuk mencapai tujuan pendidikan.

Peran strategis kepala sekolah dapat terlaksana jika kepala sekolah memiliki tiga kemampuan dasar yang penting yaitu: conceptual skills,human skills dan technical skills Wahjosumidjo (2013, p. 349). Tiga kemampuan dasar tersebut, membantu kepala sekolah dalam (a) menentukan tujuan sekolah (b) mengorganisasikan atau mengatur sekolah (c) menanamkan pengaruh atau kewibawaan kepemimpinannya (d) pengambilan keputusan serta melaksanakan perbaikan pendidikan. Konsep Wahjosumidjo diperkuat hasil riset bank dunia bahwa dalam meningkatkan mutu pendidikan maka kepala sekolah perlu memperkuat kualitas guru, mereformasi kurikulum dan pedagogi, melaksanakan desentralisasi dan manajemen berbasis sekolah, perolehan akses dan pemerataan pendidikan khusus bagi yang miskin dan kurang mampu serta penguatan anggaran pendidikan (Tobias, Wales, Syamsulhakim, \& Suharti, 2014, p. 21).

Aspek-aspek peningkatan mutu tersebut hanya dapat terealisasi dengan baik jika kepala sekolah memiliki kemampuan dan skill yang baik dalam mengarahkan, mengambil keputusan, mendelegasikan tugas atau kewenangan, membangun kolegalitas dan kerja sama. Pada aspek kemampuan mengambil keputusan penting Hoy \& Miskel (2007, p. 356) memberikan empat kriteria yang harus diperhatikan kepala sekolah. Agar kualitas putusan yang diambil berdaya pengaruh dan diterima baik maka kepala sekolah harus memperhatikan (a) Quality role, yaitu berkaitan kemampuan kepala sekolah untuk memahami penting tidaknya masalah, dan mengetahui kemampuan bawahan dalam menerima keputusannya, (b) memperhatikan Leader information rule,kepala sekolah harus sadar bahwa dalam pengambilan keputusan harus mempertimbangkan kelayakan atau ketercukupan informasi serta kemampuan pribadinya dalam memecahkan masalah 
(c) trust rule (goal congruence), kepala sekolah harus dapat membuat keputusan sendiri demi mencapai tujuan organisasi ketika menyadari bahwa bawahannya tidak punya kemampuan cukup untuk membuat keputusan dalam mencapai tujuan organisasi, (d) problem stucture rule, kepala sekolah harus dapat melibatkan bawahan untuk mengumpulkan informasi dalam memperkuat keputusan penting dan ia sendiri tidak memiliki keahlian dan informasi yang memadai dalam mengambil keputusan.

Kemampuan kepala sekolah mengarahkan guru dan karyawan, mengambil keputusan, delegasi kewenangan serta membangun kerja sama sangat tergantung dari kemampuan individu pemimpin dalam melihat situasi yang dihadapinya. Blanchard (2007, p. 169) menjelaskan bawa individu dengan tingkat kematangan tinggi memiliki pengetahuan, pengalaman dan motivasi untuk melakukan pekerjaan. Ia memiliki rasa percaya diri dan harga diri yang tinggi. Konsep ini menekankan bahwa ketika individu atau kelompok mencapai tingkat kematangan tinggi akan menunjukkan perilaku kepemimpinannya dengan baik.

Tidak ada pemimpin yang memiliki satu-satunya perilaku dalam kepemimpinanya. Ada perilaku yang kuat dalam satu gaya tertentu dan saat bersamaan ia juga memiliki perilaku lainnya dengan intensitas yang lebih rendah. Redin (Wuradji, 2008, p. 35), mengedepankan dua gaya kontras perilaku kepemimpinan dengan istilah task oriented dan relationship oriented. Masing-masing perilaku berada atau ditempatkan dalam garis kontinum yang bergerak dari level tinggi ke level rendah. Reddin menempatkan perilaku kepemimpinan dalam empat kategori yakni: "(1) high on task, but low in relationship(2) high on relationship, but low on task(3) low on task, and low on realationship (4) high on task and high on relationship."

Chung \& Meggison (Wuradji, 2008, p. 5), menjelaskan bahwa perilaku direktif sering disebut dengan "leader facilitation atau instrumental leadership."Perilaku direktif memiliki karakteristik dimana pemimpin merumuskan tujuan dan kinerja ke- lompok, memberikan tugas mengenai apa dan bagaimana kinerja yang harus dilakukan oleh guru atau staf di sekolah. Menentukan kepada siapa guru dan staf harus bertanggung jawab secara berantai (defined chain of commando). Pearce (2015, p. 46) dalam penelitiannya berjudul Creating Leaders Through the Teacher Learning and Leadership Program menunjukanbahwa: "Leadership is a skill that can be learned through professional development, mentoring, and leadership development programs." Kemampuan dan keterampilan seorang guru meningkat melalui program-program kepemimpinan seperti TLLP (Teacher Learning and Leadership Program). Program semacam ini dapat membantu guru meningkatkan kualitas dan akuntabilitas pembelajaran. Peran kepala sekolah dalam memberi pendampingan, latihan, instruksi terhadap guru dan staf untuk melakukan tugas dan pekerjaan secara tepat sangat membantu sekolah dalam mencapai tujuan. Perilaku direktif cocok diterapkan pada situasi sekolah dan penataan tugas-tugas yang belum berjalan secara baik dan maksimal. Perilaku direktif diterapkan ketika guru dan staf memiliki tingkat kemampuan dan kemandirian yang masih rendah, belum memiliki inisiatif dan tangunng jawab atau tergantung pada pengawasan instruksi pimpinan.

Perilaku supportive sering disebut juga "leader consideration, people oriented atau employee centered leadership." Perilaku supportive dicirikan oleh karakteristik pemimpin yang menunjukan perhatian pada aspek-aspek pribadi atau personal guru, pegawai dan karyawan. Pemimpin bersahabat dekat dengan guru dan karyawan, menyediakan kesempatan konsultasi secara pribadi, memotivasi bawahanuntuk mengekspresikan masalah, kebutuhan serta perasaan-perasaanya. Pemimpin mengupayakan harmonisasi atau keharmonisan dalam situasi kerja di sekolah. Giri \& Kumar (2007, p. 131), dalam penelitiannya berjudul impact of organizational climate on Job satisfaction and job performance menunjukan bahwa iklim organisasi memiliki pengaruh signifikan dalam kepuasan kerja dan kinerja. Pemimpin berperan besar terhadap 
iklim sekolah, kepuasan kerja dan kinerja guru. Perilaku supportive lebih cocok diterapakan dalam situasi dimana sekolah dengan tugas atau kegiatan yang sudah tertata rapih dan disiplin. Penerapan perilaku supportive berfungsi untuk mengurangi rutinitas dan tekanan-tekanan pekerjaan yang tinggi. Perilaku ini cocok untuk situasi guru dan karyawan yang telah mampu melaksanakan tugas dengan baik, memiliki kemandirian, kerja sama serta tanggung jawab tinggi terhadap tugas dan pekerjaan mereka.

Perilaku partisipatif sering disebut juga dengan "group management atau team management" (Wuradji, 2008, p. 37). Pemimpin berbagi tanggung jawab dan melakukan tugas-tugas dan pekerjaan di sekolah. Kepala sekolah mengajak anggota kelompok untuk bersama-sama merumuskan kebijakan sekolah dan garis-garis besar panduan untuk implementasi program sekolah. Pemimpin memberi kepercayaan kepada guru dan karyawan untuk menata dan merancang tugas serta pekerjaan mereka. Pemimpin dapat melakukan negosiasi terhadap setiap perbedaan atau kesulitan yang dihadapi oleh guru dan karyawan. Barr \& Duke (2004, p.255) dalam artikel mereka berjudul What Do We Know About Teacher Leadership? Findings From Two Decades of Scholarship, memaparkan bahwa pelibatan guru, staf atau karyawan dalam kepemimpinan ikut mempengaruhi kapasitas organisasi menuju profesionalisme, perbaikan pembelajaran siswa serta potensial untuk mengembangkan kepemimpinan guru.

\section{Metode}

Penelitian ini dilakukan dengan pendekatan kualitatif dengan jenis studi kasus deskriptif eksplanatoris karena mengeksplorasi fenomena yang kompleks dari individu atau organisasi atau program yang kompleks seperti yang terjadi dalam dunia pendidikan (Yin, 2009, p. 4; Baxter \& Jack, 2008 , p. 544). Kajian data riset ini terfokus pada perihal bagaimana dan mengapa fenomena unik dari praktik kepemimpinan kepala sekolah sehingga membutuhkan ke- pekaan terhadap konteks riil (real life) kepemimpinan yang diterampakan di sekolah (Yin, 2014, p. 9). Data yang diperoleh merupakan data langsung dari sumber data yang tepat (informan) pada objek penelitian yaitu TK Kanisus Yogyakarta.

Waktu penelitian dilakukan dari bulan Juli dan Agustus tahun 2015 melalui kegiatan pra-riset. Penelitian secara mendalam dimulai dari bulan Oktober 2015 sampai bulan Maret 2016. Tempat penelitian di TK Kanisius Demangan Baru, TK Kanisius Kotabaru dan TK Kanisius Wirobrajan Yogyakarta.

Subjek penelitian dari riset ini berjumlah 13 orang dengan rincian 3 kepala sekolah, 8 guru dan 3 komite sekolah untuk ketiga sekolah yang dipilih secara purposive yakni TK Kanisius Demangan Baru, TK Kanisius Kotabaru dan TK Kanisius Wirobrajan. Karakteristik subjek penelitian dipilih dengan mempertimbangkan bahwa ketiga sekolah ini memenuhi kriteria sekolah yang berkembang cukup pesat, maju dan memiliki jumlah murid yang banyak. Kriteria kedua sekolah dengan perkembangan mapan dan stabil dimana penerimaan siswa tiap tahun ajaran cukup merata tiap tahun. Kriteria ketiga adalah sekolah dengan kondisi menurun jumlah siswanya pada lima tahun terakhir. Objek penelitian ini adalah kepemimpinan kepala TK pada aspek (a) kepala TK dalam mengarahkan guru dan karyawan (b) Kepala TK dalam mengambil keputusan (c) kepala TK dalam mendelegasikan tugas dan kewenangan (d) Kepala TK dalam pengembangan kerja sama.

Teknik pengumpulan data menggunakan teknik observasi dan wawancara mendalam terhadap semua sumber data yang ada pada tiga sekolah.Teknik observasi dilakukan dengan cara mengamati perilaku, kejadian atau kegiatan yang terjadi di ketiga sekolah yang berkaitan dengan aktivitas kepala sekolahdalam melaksanakan fungsi kepemimpinan. Observasi ini berfungsi untuk mencatat fenomena, fakta dari objek yang diteliti. Teknik wawancara digunakan untuk menggali informasi secara langsung dari sumber data baik kepala se- 
kolah, guru dan komite sekolah tentang keempat apsek dalam pelaksanaan kepemimpinan kepala TK Kanisius di tiga sekolah tersebut.

Validasi data yang digunakan dalam riset ini menggunakan triangulasi. Proses triangulasi sumber melalui konfirmasi dan verifikasi sumber data baik kepala sekolah, guru dan orang tua terhadap aspek kepemimpinan pada empat apsek yang diteliti. Kevalidan data diuji dan diukur dengan membandingkan informasi dari sumbersumber data sampai mendapatkan data yang valid dan reabel sehingga akuntabilitas atau kredibilitas data dapat dipertanggung jawabkan. Triangulasi teknik digunakan dengan melakukan crosscek data wawancara dan observasi untuk memastikan informasi dan data yang akurat dari sumber data baik wawancara kepala TK, guru dan komite sekolah. Triangulasi teknik ini digunakan untuk memastikan validitas dan kredibilitas data.

Analisis data yang digunakan dalam penelitian ini adalah analisis interaktif model Milles \&Huberman (Norman \& Yvonna, 1994, p. 429). Tahapan analisis data dimulai sejak pengumpulan data, kemudian data disajikan dalam bentuk rangkuman hasil wawancara yang memaparkan temuan antarsitus (temuan dari ketiga sekolah) untuk empat aspek kepemimpinan kepala TK dalam menjalankan fungsi mengarahkan guru dan staf, mengambil keputusan, melakukan delegasi tugas dan kewenangan serta kerja sama. Tahapan display data ini dibantu dengan proses pengkodingan data wawancara dari setiap sumber data, dan dipaparkan hasil wawancara dari setiap informan dalam bentuk tabel temuan antarsitus. Susudah tahapan display data dilakukan reduksi data, memilah intisari informasi penting atau relevan dari empat aspek kepemimpinan pada masing-masing sekolah. Sesudah reduksi data wawancara dan data observasi dilakukan penarikan kesimpulan untuk menemukan model kepemimpinan dan perilaku kepemimpinan pada masing-masing sekolah. Analisis data ini dilakukan secara interaktif sehingga proses analisis data bergerak dari pengumpulan data, display, reduksi dan verifikasi bisa juga sebaliknya sampai menemukan interprestasi dan kesimpulan yang lebih akurat dan tepat sehingga analisis data riset ini bersifat induktif.

\section{Hasil Penelitian}

Kepala TK dalam Mengarahkan Guru dan Karyawan pada Pelakasanaan Tugas dan Tanggung jawab di sekolah

Pada aspek pengarahan yang kepala TK Kanisius Demangan Baru melalui wawancara diungkapkan bahwa: membangun team work dan menghabiskan sebagian besar waktu untuk meningkatkan program instruksional sekolah bersama guru dan stafnya. Peran pengarahan dilakukan sejak perumusan perencanaan program tahunan dan semesteran. Kemampuan mengarahkan ini terwujud dalam upaya mencapai keberhasilan sesuai indikator pencapaian visi dan misi sekolah. Hasil amatan menunjukan bahwa Kepala TK mengarahkan pada target mutu tinggi dan hal ini terungkap dari upaya nyata kepala TK dalam memerankan fungsi pemimpin pembelajar.

Kepala TK memerankan dengan baik fungsi pemimpin pembelajar melalui berbagai kegiatan akademik seperti; menekankan tertib administrasi, merencanakan kurikulum, pameran buku, program sempoa, kunjungan rutin ke percetakan Kanisius untuk menemukan keunggulan-keunggulan dari bahan bacaan. Kepala TK juga mengarahkan bagaimana para guru didorong untuk memiliki keterampilan dan penguasaan internet sebagai sumber belajar bagi guru (expert power).

Kepala TK Kotabaru menghadapi situasi menurunnya jumlah peminat. Dalam dua tahun terakhir siswa menurun drastis. Situasi ini menuntut Kepala TK Kotabaru untuk mengembalikan citra dan popularitas TK Kotabaru sebagai TK perintis di kota Yogyakarta. Kepala TK Kotabaru dalam menjalankan fungsi pengarahan berupaya memerankan dengan baik "fungsi pemimpin instruksional." Hasil amatan bahwa: kegiatan "morning briefing" merupakan 
contoh nyata bagaimana pentingnya arahan setiap hari dilakukan oleh kepala TK yang ditandai dengan perilaku kepemimpinan direktif. Kepala TK mengarahkan fungsi perencanaan pembelajaran dengan agenda progam tahunan mulai dari rekrutmen siswa baru sampai kegiatan tutup tahun ajaran. Beberapa kegiatan akademik seperti karya wisata, outbound, panggung gembira, drumb band, tari, renang dan PIA dilakukan untuk meningkatkan prestasi siswa dan sekolah. Program khusus seperti komputer, musik, melukis dan bahasa Inggris, kegiatan rutin guru (IGTKI Cabang Gondokusuman, TPSPP atau Radio Edukasi. semua ini diarahkan oleh kepala TK Kotabaru untuk mencapai prestasi siswa dan sekolah.

Tabel 2. Praktik dan Perilaku Kepemimpinan di TK Kanisius Demangan Baru

\begin{tabular}{ll}
\hline $\begin{array}{c}\text { Aspek-Aspek } \\
\text { Kepemimpin- }\end{array}$ & \multicolumn{1}{c}{ Indikator praktik dan perilaku } \\
kepemimpinan di TK Demangan Baru
\end{tabular}

Sumber: Analisis interactive data penelitian 2016
Tabel 3. Praktik dan perilaku kepemimpinan di TK Kanisius Kotabaru

\begin{tabular}{ll}
\hline $\begin{array}{c}\text { Aspek-Aspek } \\
\text { Kepemimpin- } \\
\text { an }\end{array}$ & \multicolumn{1}{c}{ Indikator praktik dan perilaku } \\
kepemimpinan
\end{tabular}

Sumber: Analisis interactive data penelitian 2016

Kepala TK Wirobrajan dalam melaksanakan fungsi pengarahan terhadap guru dan staf terjadi melalui rapat atau pertemuan bersama untuk membicarakan program dan pelaksanaan program sekolah. Peran utama pengarahan kepala TK terfokus pada tujuh program sekolah yakni: (1) program umum (2) program pengajaran (3) program kemuridan (4) personalia (5) peralatan dan perlengkapan sekolah (6) keuangan (7) hubungan sekolah dengan instansi pemerintah dan masyarakat. Dari hasil wawancara guru diungkapkan bahwa: Renstra ini dimplementasi di dalam program mingguan, 
bulanan dan tahunan. Renstra juga didukung dengan beberapa program penunjang seperti program mingguan menyangkut kegiatan upacara bendera, kegiatan bahasa inggris, musik, menggambar, senam, menari, kegiatan rohani dan taman gisi. Fungsi pengarahan kepala TK kepada guru dan staf juga berkaitan dengan program bulanan seperti, kunjungan (home visit), penimbangan berat badan dan tinggi badan, jalan-jalan, out bound, kerja bakti, lombalomba serta pertemuan bulanan orang tua wali murid.

Tabel 4. Praktik dan perilaku kepemimpinan di TK Kanisius Wirobrajan

\begin{tabular}{|c|c|}
\hline $\begin{array}{l}\text { Aspek-Aspek } \\
\text { Kepemimpin- } \\
\text { an }\end{array}$ & $\begin{array}{l}\text { Indikator praktik dan perilaku } \\
\text { kepemimpinan }\end{array}$ \\
\hline Mengarahkan & $\begin{array}{l}\text { - Mengarahkan dengan pendekatan } \\
\text { "Morning Briefing" untuk kegiatan } \\
\text { harian, mingguan dan bulanan. } \\
\text { - Nilai-nilai Kanisius terserap dalam } \\
\text { semua aktivitas sekolah } \\
\text { - Mengarahkan melalui teladan dan } \\
\text { contoh "sedikit bicara banyak berbuat" } \\
\text { - Memotivasi guru dan staf }\end{array}$ \\
\hline $\begin{array}{l}\text { Megambilan } \\
\text { Keputusan }\end{array}$ & 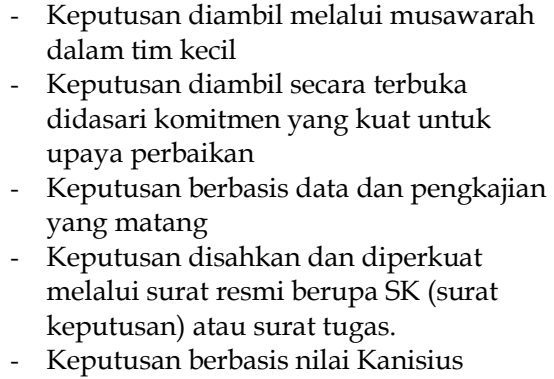 \\
\hline $\begin{array}{l}\text { Mendelegasik } \\
\text { an Tugas dan } \\
\text { Kewenangan }\end{array}$ & $\begin{array}{l}\text { - Pendelegasian sangat sering dilakukan } \\
\text { karena jumlah personil guru yang } \\
\text { terbatas. } \\
\text { - Pendelegasiaan baik tugas pokok } \\
\text { maupun tugas khusus (Mengajar dan } \\
\text { membimbing) dan administrasi } \\
\text { - Pendelegasian melalui SK } \\
\text { - Pendelegasian dilakukan } \\
\text { mempertimbangkan kemendesakan } \\
\text { tugas, kesibukan dan kemampuan guru }\end{array}$ \\
\hline $\begin{array}{l}\text { Melaksanakan } \\
\text { Kerja Sama }\end{array}$ & $\begin{array}{l}\text { - Menekankan hubungan personal } \\
\text { relationship dan social relationship dengan } \\
\text { orang tua dan komite sekolah } \\
\text { - Kerja sama gugus guru } \\
\text { - Kerja sama dalam bidang religius, social, } \\
\text { seni dan budaya, kesehatan, } \\
\text { - Kerja sama dinas pendidikan dan } \\
\text { kebudayaan kota, perguruan tinggi dan } \\
\text { Bank }\end{array}$ \\
\hline $\begin{array}{l}\text { Perilaku } \\
\text { kepemimpin- } \\
\text { an }\end{array}$ & $\begin{array}{l}\text { - Perilaku kepemimpinan partisipatif } \\
\text { (participative leadership) }\end{array}$ \\
\hline
\end{tabular}

Sumber: Analisis interactive data penelitian 2016
Pengambilan Keputusan yang dilakukan Kepala TK

Pada aspek pengambilan keputusan Kepala TK Demangan Baru dilakukan berdasarkan keputusan bersama dan memperhatikan manfaat serta mengedepankan transparansi. Keputusan yang diambil kepala TK selalu dapat memastikan bahwa semua keputusan selalu bisa diukur keberhasilan maupun kegagalannya melalui program-program sekolah. Sebut saja misalnya dalam mensukseskan kegiatan les sempoa, les nari, taman gizi, kegiatan mini trip, natal bersama. Kepala TK sebagai pimpinan memantapkan program bersama guru, karyawan dan komite sekolah. Data wawancara berikut memperkuat perilaku kepemimpinan supportif.

Pengambilan keputusan oleh kepala TK Kotabaru berdasarkan hasil wawancara dan amatan bahwa: setiap keputusan dilakukan melalui musawarah bersama. Pengambilan keputusan bersifat, terbuka dan memperhatikan kepentingan bersama. Perencanaan program kegiatan sekolah direncanakan dan diputuskan bersama guru, staf dan orang tua. Semua warga sekolah saling mendukung dan memberikan komitmen untuk mensukseskan setiap program kegiatan. Hasil rapat disampaikan secara resmi kepada pihak orang tua dan yayasan.

Pengambilan keputusan oleh kepala TK Wirobrajan berdasarkan wawancara dan amatan dilakukan dengan kesepakatan bersama, melibatkan peran guru dan staf. Kepala TK mengajak bawahannya untuk membuat pilihan akhir dari semua alternatif yang ada. Namun ada juga keputusan yang mengharuskan seorang kepala TK secara otonom, berdasarkan keyakinan dan kewenangannya memutuskan tanpa perlu lagi ada musyawarah bersama guru dan karyawan.

Pendelegasian Tugas dan Kewenangan yang dilakukan Kepala TK

Pada aspek pendelegasian tugas dan kewenangan kepala TK Kanisius Demangan Baru biasanya berdasarkan pada per- 
timbangan waktu, kesibukan dari masingmasing guru serta jenis tugas dan kegiatan maupun keahlian guru. Dari hasil wawancara dengan guru menjelaskan bahwa: pendelegasian diberikan untuk tugas khusus dan tugas rutin, tugas rutin atau pokok mengajar sudah ditentukan tanggung jawabnya masing-masing baik itu mengajar maupun tugas tambahan lainnya. Tugas khusus disesuaikan dengan kondisi siapa yang paling berhak sesuai kemapuan juga waktu sehingga tujuan dari pendelegasian itu dapat tercapai. Pendelagasian semuanya berdasarkan surat resmi. Tugas-tugas yang diberikan selalu didasarkan pada kepercayaan bahwa semua orang mampu dan dapat menjalankan peran dan tanggung jawab serta amanah yang diberikan. Pendelegasian tugas dan kewenangan kepala TK Kanisius Demangan Baru selalu berhubungan dengan hal-hal yang berkaitan dengan aspek pengajaran dan peran managerial. Kedua peran ini didelegasikan dalam pelaksanaan tugas pengajaran melalui pembagian tugas dan kewenagan mengajar dan dalam setiap program kegiatan khusus dan rutin yang dilakasanakan di sekolah.

Pendelegasian kewenangan kepala TK Kanisius Kotabaru, berdasarkan amatan dan wawancara dilakukan selalu dalam konteks dialog, menanyakan kesediaan dan kesangguban bawahan. Pendelegasian didukung secara legal melalui surat resmi untuk memastikan pelaksanaan tugas dan kewenangan dapat berjalan dengan baik dan penuh tanggung jawab. Wawancara guru berikut ini menjelaskan hal-hal yang berkaitan dengan pendelegasian tugas dan kewenangan kepala TK. Pendelegasian tugas dan kewenangan kepala TK Kotabaru didasarkan pada rekomendasi formal. Hal ini menunjukan bahwa kepala TK memahami dengan baik prosedur dan penerapan pendelegasian tugas berbasis tertib atau disiplin administrasi. Hal ini diakui sangat mendukung kejelasan tugas dan siapa yang bertanggung jawab dalam setiap kewenangan yang diberikan untuk dilakukan saat kepala TK tidak berada di tempat atau berhalangan hadir.Pendelegasian tugas dan kewenangan kepala TK Kanisius Wirobrajan selalu menguatamakan kepercayaan dan keyakinan bahwa guru dan staf memiliki kemampuan, keahlian dan kompetensi untuk melaksanakan tugas dan tanggung jawabnya. Dari pengakuan semua guru dapat menjelaskan perilaku partisipatif kepemimpinan kepala sekolah dalam pendelegasian tugas dan kewenangan. Pendelegasian tugas oleh kepala TK Kanisius Wirobrajan dilakukan secara profesional dengan memperhatikan kemampuan, skill, jenis tugas dan pekerjaan, kesibukan dan tanggung jawab yang sementara dikerjakan. Dengan demikian kecil kemungkinan terjadinya kekeliruan atau miss komunikasi karena sejak awal pendelegasiaan itu sudah dikoordinasi dan dikomunikasikan dengan jelas dan disertai dengan rekomendasi surat penunjukan secara resmi sebagai bukti dan dukungan bagi pelaksaan tugas tersebut.

Pengembangan Hubungan Kerja Sama yang dilakukan Kepala TK

Pada aspek pengembangan kerja sama TK Kanisius Demangan Baru dilakukan dalam beberapa bidang seperti bidang religius, kesehatan, social kemasyarakatan serta seni budaya. Peran kerja sama orang tua dengan pihak sekolah di bawah koordinasi kepala TK berkaitan dengan program sekolah baik program mingguan, bulanan dan tahunan. Hasil observasi menunjukan bahwa banyak program sekolah melibatkan orang tua dan masyarakat. Dalam wawancara dengan kepala TK dan Guru diperoleh informasi bahwa: kerja sama dengan orang tua dan masyarakat berhubungan dengan program rutin mingguan seperti, upacara bendera, kegiatan bahasa inggris, musik, menggambar, senam, menari, religius dan taman gisi. Program bulanan seperti, kunjungan (home visit), penimbangan berat badan dan tinggi badan, jalan-jalan, kegiatan belajar di luar sekolah (out bound), kerja bakti dan lomba-lomba serta pertemuan bulanan dengan orang tua wali murid. Tugas pokok kepala TK dalam pelaksanaan kerja sama adalah mengarahkan dan mengkoordinasikan program- 
program tahunan seperti MOS (masa orientasi siswa baru), pentas seni, Sempoa, rekreasi, kegiatan APP (Aksi Puasa Pembangunan), kegiatan masa Advent, Natal dan Paskah, HUT Sekolah, Hari Petrus Kanisius dan BKSN (Bulan Kitab Suci Nasional). Program kegiatan TK Kanisius Demangan Baru dilakukan atas inisiatif orang tua atau komite sekolah dalam mensponsori semua kegiatan siswa. Semua program penunjang melibatkan orang tua secara penuh. Pada aspek kerja sama ini peran komite sekolah sangat penting dalam merencanakan dan mensponsori semua kegiatan siswa sedangkan peran kepemimpinan kepala teka lebih supportif sifatnya.

Kerja sama yang dilakukan kepala TK Kanisius Kotabaru melibatkan guru, staf, orang tua siswa, komite sekolah dan masyarakat. Contoh nyata kerja sama ini dalam persiapan Natal bersama. Sekolah dan pihak paroki bersama-sama menyelenggarakan natal bersama. Kerja sama dengan masyarakat dilakukan dalam bidang seni budaya melalui lomba tari pada malam pesta seni di alun-alun. Sekolah melibatkan umat dalam kegiatan misa setiap Jumat pada awal bulan di Gereja Kotabaru. Kerja sama sekolah dan orang tua undalam aksi social penggalangan dana untuk warga kurang mampu pada hari raya besar gereja seperti Natal dan Paskah. Peran kepemimpinan kepala TK Kanisius Kotabaru lebih bersifat direktif karena kepala TK harus memberikan arahan, instruksi dalam berbagai kegiatan mengingat sekolah ini berada dalam situasi membangun kembali kepercayaan masyarakat dan membenahi kembali administrasi sekolah yang kembali di tata kembali dalam dua tiga tahun masa kepemimpinan kepala TK yang baru. Hasil wawancara menjelaskan kontek kerja sama di TK Kanisius Kotabaru, bahwa: kerja sama terwujud melalui program-program sekolah, saling mendukung dan terlibat untuk kemajuan TK Kanisius Kotabaru. Membangun kegiatan dengan orang tua dalam penyusunan program-program sekolah. Saling mensupport, saling mengasihi dan menghormati sebagai komunitas sehingga jika ada permasalahan selalu berdiskusi untuk mencari solusi bersama.

Kerja sama yang dikembangkan di TK Kanisius Wirobrajan bersama orang tua siswa tidak hanya sekedar tegur sapa semata tetapi terjalin komunikasi personal dan sosial yang kuat. Hubungan paling intens adalah dengan komite sekolah karena peran komite sangat membantu dalam mensukseskan kegiatan sekolah seperti kegiatan mini trip, lomba drum band, kegiatan natal, sanggar tari, lomba mewarnai tingkat TK dan PAUD sekota Yogyakarta. Hubungan dengan pemerintah secara khusus dengan Dinas pendidikan Kebudayaan umumnya berkaitan dengan tugas kedinasan seperti pelaksanaan program pemerintah. Kerja sama dalam optimalisasi Dana Bantuan Operasional Sekolah (BOS), laporan perkembangan data statistik semesteran atau tahunan sekolah, laporan kinerja guru dan kepala sekolah serta kegiatan akreditas sekolah. Hubungan dengan masyarakat dilakukan melalui pemberdayaan masyarakat setempat yakni tenaga keamanan, tenaga kebersihan, adanya kantin sekolah yang dikelola masyarakat. Menjelang hari haru besar perayaan keaagamaan seperti natal sekolah bersama orang tua mengadakan bakti sosial dan penggalan dana sosial untuk keluarga kurang mampu di sebuah desa di wilayah Yogyakarta. Kegiatan ini bertujuan untuk mewujudkan visi sekolah yang berdasarkan nilai-nilai Kanisius.

Analisis

Kepala TK dalam Mengarahkan Guru dan Karyawan pada Pelakasanaan Tugas dan Tanggung Jawab di sekolah

Peranan kepala TK sebagai fungsi pengarahan terlihat memiliki alasan yang kuat baik dari hasil amatan maupun dari hasil wawancara, bahwa pengarahan dilakukan untuk mencapai tujuan yang telah ditentukan, dalam rangka menjalankan visi yang ditetapkan yayasan, serta komitmen yang tinggi dari kepala TK itu sendiri, dalam menjalankan peranannya sebagai pemimpin di sekolah. Kepala TK Demangan Baru terlihat supportif, karena guru dan 
karyawan sebagian besar memiliki pengalaman yang cukup baik, tetapi sebagai pemimpin tetap memerankan fungsi pengarahan sebagaimana mestinya dalam menjalankan kepemimpinan. Selain hal itu yang menjadi alasan bahwa pengarahan perlu dilakukan untuk memotivasi, memberikan kepuasan kepada guru dan karyawan serta memberikan rasa optimis untuk masa depan, sehingga dapat menghasilkan efektivitas kerja yang tinggi dan diharapkan mampu membuahkan hasil yang bermanfaat bagi sekolah dan bagi dirinya sendiri. Upaya dan kepemimpinan yang dilakukan oleh kepala sekolah TK Demangan Baru memperlihatkan suatu kematangan leadership yang baik sehingga memberikan dampak kepada hasil. Hal ini sejalan dengan konsep Blanchard (2007, p. 169) menjelaskan bahwa kepala sekolah sebagai individu dengan tingkat kematangan tinggi yang memiliki pengetahuan, pengalaman akan termotivasi untuk melakukan pekerjaan dan tanggung jawab secara profesional. Tindakan kepemimpinan tersebut terlihat melalui perilaku kepemimpinan yang diperankan kepala TK Demangan Baru, dan didukung oleh tingkat kematangan yang dimiliki sebagian besar guru dan karyawan. Hal ini ditunjukan dalam faktual kepemimpinan sehari-hari dimana sebagai kepala TK ia tidak memberikan instruksi yang banyak tetapi memberi support untuk setiap tugas dan tanggung jawab yang dilakukan oleh guru dan karyawan di sekolah.

Pada situasi sekolah yang sedikit berbeda, kepala TK Kotabaru memerankan fungsinya sebagai pengarah sehingga lebih berorientasi pada perilaku direktif yang dibuktikan dengan temuan lapangan. Keadaan sekolah yang membutuhkan perhatian yang tinggi dari kepala TK. Daya kepemimpinan yang ditunjukan memberi pengaruh langsung. Hal ini terindikasi dari sosok dan gaya kepala sekolah yang berfungsi sebagai orang yang menciptakan perubahan, memberi dorongan dan petunjuk yang efektif kepada guru sehingga mereka merasa digerakan dan secara sadar mau melakukan apa yang dikehendaki atau diperintah oleh kepala sekolah sebagai pemim- pin (Wahjosumidjo, 2013, p. 38). Pola perilaku kepemimpinan ini sangat penting dilakukan untuk memberi daya pengaruh langsung (direct) Hal ini dimotivasi juga oleh kebutuhan untuk mengembalikan mutu dan kultur sekolah yang memiliki sejarah yang kuat dengan tradisi prestasi yang gemilang. Karena itu peran pengarah, peran instruksi dilakukan kepala sekolah dalam seluruh gerak layanan dan bimbingan siswa dalam proses belajar dan seluruh aktivitas edukatif di sekolah. Tujuannya adalah mencapai prestasi sekolah, memotivasi, meningkatkan kinerja guru dan karyawan serta usaha pencapaian tujuan dengan ditandai adanya perencanaan, pelaksanaan dan monitoring.

Pengarahan yang dilakukan kepala TK Kanisius Wirobrajan dibuktikan dengan mengajak guru dan karyawan untuk bersama-sama merumuskan garis-garis besar program sekolah yang akan dilakukan. Sebagai kepala TK juga memberikan keleluasaan kepada rekan kerjanya untuk menata dan merancang tugas pekerjaannya sendiri tetapi berpedoman pada ketentuan secara umum. Dalam hal ini pengarahan sebagai upaya untuk mengelola segala sumber daya menuju pencapaian tujuan sesuai visi dan misi sekolah. Hal yang dominan di TK Wirobrajan adalah team work yang baik. Tim kerja yang baik sangat membantu membantu efesiensi kerja dan kordinasi kepala sekolah. Semakin efektif tim kerja akan semakin mudah dalam eksekusi dan implementasi kerja. Tim kerja dan koloborasi yang dibangun oleh kepala sekolah sangat menentukan hasil akhir dari sebuah kepemimpinan karena menurut konsep kepemimpinan Blanchard (2007, p. 171) bahwa membangun tim yang efektif seperti halnya dengan membangun sebuah organisasi besar, dimulai dengan merumuskan gambaran tujuan serta target yang harus dicapai. Upaya ini telah diwujudkan dengan baik oleh Kepala TK yang berupaya keras membagun tim kerja yang efektif dengan melibatkan guru dan karyawan dalam merencanakan program sekolah. Peran dan partisipasi aktif menjadi kunci dari management kepemimpinan kepala TK. Pe- 
rilaku kepemimpinan partisipatif yang diperankan oleh kepala TK Wirobrajan semakin memperkuat dan mendukung visi dan misi sekolah. Kepemimpinan partisi-patif merupakan sebuah tindakan yang menunjukan bahwa subjek guru sudah memiliki otonomi dan tanggung jawab yang baik dengan semua tugas instruksional di sekolah. Kepemimpinan partisipasi menunjukkan bahwa kepala sekolah memiliki tingkat kepercayaan yang baik terhadap bawahan atau rekan kerjanya sehingga ia hanya mengambil peran dan fungsi untuk mempengaruhi dan memberdayakan. Hal ini sesuai dengan konsep kepemimpian yang menginspirasi, karena pemimpin adalah seautu seni untuk mempengaruhi dan menginspirasi orang lain untuk bekerja mencapai tujuan bersama yang telah ditentukan. Ketiga kepala sekolah TK Kanisius telah berupaya dengan model kepe-mimpinannya masingmasing dan berupaya untuk mempengaruhi dan mengarahkan para guru, staf dan pihak lain seperti orang tua dan komite sekolah untuk secara bersama-sama mencapai tujuan sebagaima-na yang ditetapkan dalam visi, misi dan tujuan sekolah berdasarkan pada nilai-nilai yang diyakini sesuai profesionalisme seorang pemimpin (Davies, 2006, p. 19).

Kepala TK dalam Pengambilan Keputusan di Sekolah

Peranan sebagai pemberi keputusan merupakan hal yang biasa dilakukan, terbukti melalui amatan dan wawancara bahwa keputusan dilakukan dalam menjalankan kepemimpinan, terutama berkaitan dengan program-program sekolah. Pengambilan keputusan yang diperankan kepala TK Demangan Baru, melalui pendekatan sistematis, mulai dari pengumpulan fakta-fakta, melalui musyawarah bersama guru dan karyawan, dan penentuan yang matang dari alternatif yang ada serta berpedoman pada nilai-nilai yang diyakini yaitu nilai Kanisius. Melalui pendekatan sitematis tersebut terbukti mampu mengambil keputusan dengan baik. Hal ini dilakukan untuk kepentingan sekolah dalam menjalankan roda kepemimpinan sesuai visi yang telah ditetapkan. Selain itu keputusan dilakukan untuk membuat keputusan final dalam mengatur, mengelola dan mengendalikan kelompok di sekolah.

Pemberian keputusan dilakukan dalam rangka mencapai tujuan yang telah ditentukan serta memecahkan persoalan yang sedang terjadi. Kepala TK Kanisius Kotabaru menjalankan fungsinya sebagai pengambil keputusan dengan baik, terbukti bahwa setiap keputusan yang diberikan berdasarkan musyawarah, identifikasi masalah serta memperhatikan asas manfaat. Dalam hal ini keputusan diharapkan mampu mengembalikan prestasi sekolah, memecahkan permasalahan, meningkatkan komitmen serta kinerja guru dan karyawan. Kepala sekolah TK Demangan baru menunjukkan kapasitas pada aspek teknik kepemimpinan yang mumpuni. Hal terlihat dari upaya yang efektif dalam mengoptimalkan sumber daya keuangan, manusia dan fisik sekolah dengan manajemen dan sistem organisasi yang baik sehingga berkontribusi pada pencapaian program sekolah seperti mengupayakan bangunan fisik gedung sekolah yang baru untuk menjawab tuntutan kebutuhan belajar siswa saat ini. Ia juga berhasil dalam menumbuhkan lingkungan belajar yang aman, terarah dan inklusif. Ia mampu mengembangkan kapasitas teknik dan kemanusiaan (technic and human capacity) sebagai kepala sekolah yang tampak dalam relasi persoanal dan sosial yang konstruktif, menghormati staf, siswa, orang tua siswa dan pemangku kepentingan lainnya sehingga tercipta suatu kultur sekolah yang mampu mempromosikan visi masa depan sekolah dengan dasar nilai-inilai pendidikan Kanisius. Kepemimpinanya mampu mensinergiskan daya dukung dan komitmen sehingga mampu menyelaraskan tujuan dan harapan para pemangku kepentingan untuk mewujudkan potensipotensi siswa (OECD, 2008b, p. 192).

Di TK Wirobrajan, kepala TK dan para guru memutuskan untuk tidak mengajarkan anak-anak untuk harus bisa menulis dan membaca dengan beban PR tetapi lebih memberikan pengenalan, lebih pada orientasi permaian. Hal ini berbeda dengan 
di TK Kanisius Demangan Baru, siswa harus bisa menulis dan membaca jika menyelesaikan TK Besar sehingga ada program belajar sempoa dan sejenisnya. Kepala TK yakin bahwa bersama para gurunya mereka memiliki pengalaman dan kemampuan teknis yang memungkinkan anak jika menyelesaikan TK memiliki kemampuan untuk bisa membaca dan menulis karena sudah diperkenalkan dan anak sudah belajar dengan bahagia dan gembira. Inilah keputusan dan dasar pedagogik yang diambil oleh kepala TK bersama tim guru. Karena itu yang ditanamkan dalam tim sekolah ini adalah kemampuan bekerja sama dengan orang lain, kemampuan menyelesaikan tugas secara produktif, disiplin kerja, kemampuan berkomunikasi yang baik serta semangat bekerja keras dan cerdas. Pemberian keputusan yang dilakukan menggambarkan pendekatan partisipatif, bahwa kepala TK ini menempatkan kelompok sebagai totalitas yang memiliki andil dalam mengambil tanggunjawab berkaitan dengan pengambilan keputusan. Proses pengambilan keputusan dan pemecahan masalah dilakukan secara bersama. Hal ini bertujuan membuat semua anggota merasa puas, dan akhirnya berdampak pada peningkatan kinerja dan produktivitas sekolah. Kepemimpinan yang diperankan oleh ketiga kepala TK Kanisius tersebut menunjukkan adanya upaya memperbesar dan memperkuat tingkat kinerja guru dan karyawan melalui penguatan keyakinan, nilainilai, motivasi, keterampilan, pengetahuan serta kondisi yang nyaman di sekolah (Leithwood, Harris \& Hopkins, 2008, p. 29). Dengan demikian kepemimpinan kepala TK Kanisius mampu memberikan keputusan yang tepat dalam menjalankan visi atau pencapaian tujuan.

Kepala TK dalam Pendelegasian Tugas dan Kewenangan di Sekolah

Pendelegasian yang dilakukan kepala TK Demangan Baru tentu tidak terlepas dari proses yang matang, melalui pengkajian, menentukan tugas yang akan didelegasikan dan mempersiapkan untuk diserahkan kepada guru dan karyawan. Dalam menjalankan fungsi pendelegasian, tidak hanya menyerahkan tugas dan tanggung jawab tetapi kepala TK memberikan motivasi kepada yang didelegasi, membuat persetujuan serta memantau perkembangan sehingga kepala TK tidak kehilangan otoritasnya sebagai pendelegasi. Penyerahan tugas dan kewenangan perlu dilakukan, menurut pengakuan kepala TK bahwa pendelegasian merupakan kekuatan dalam menjalankan program sekolah. Selain itu pendelegasian dilakukan sebagai bentuk pelatihan yang diberikan kepada guru dan karyawan, dan memperluas keterampilan serta kemahiran guru dan karyawan dalam peranannya di sekolah.

Pendelegasian yang dilakukan kepala TK Kanisius Kotabaru untuk mencapai tujuan yang telah ditentukan. Keterbatasan guru dan karyawan tidak menjadi faktor penghambat tetapi sebaliknya sebagai pendorong dalam menentukan kebijakan. Dalam hal ini pendelegasian sebagai kunci utama sehingga segala pekerjaan dapat terselesaikan. Selain itu pendelegasian sebagai sarana untuk memberikan tanggung jawab, melakukan penilaian dan meningkatkan keyakinan serta kesediaan guru dan karyawan untuk berinisiatif dalam mencapai tujuan.

Pendelegasian yang dilakukan kepala TK Kanisius Wirobrajan kepada guru dan staf secara profesional, mengutamakan pada pencapaian tujuan organisasi secara keseluruhan dan tetap pada otoritasnya dalam memantau dan pengendalian terhadap pelaksanaan suatu kebijakan. Pendelegasian semacam ini sejalan dengan yang dikemukan Wuradji (2008, p. 99) yaitu: pendelegasian bertujuan untuk memberikan semangat dan dukungan kepada semua anggota, mendemonstrasikan semangat kekeluargaan dan kolegalitas memberikan tanggung jawab dan saling mempercayai satu sama lain, mendorong semangat kerja staf dan pengembangan kreativitas.

Kepala TK dalam Mengembangkan Hubungan Kerja Sama di Sekolah

Pengembangan kerja sama yang dilakukan kepala TK Demangan Baru terlihat 
sudah berjalan secara efektif. Guru, karyawan dan orang tua terlihat sangat partisipatif dalam berbagai kegiatan dan program yang dilakukan, dalam menjalankan visi dan misi sekolah. Dalam hal ini sangat terlihat bahwa sebagai kepala TK memberikan supportive yang tinggi kepada guru, karyawan maupun orang tua melalui kerja sama dalam perencanaannya, pelaksanaan maupun monitoringnya. Dengan demikian kerja sama dibangun untuk menjalankan visi dan misi sekolah, sebagai upaya mencerdaskan dan membentuk karakter anak didik kearah tercapainya tujuan nilai-nilai pendidikan, sosial, kepribadian dan karier guru itu sendiri dalam jangka pendek maupun jangka panjang.

Pengembangan hubungan kerja sama yang dilakukan kepala TK Kanisius Kotabaru, tergambar dengan jelas sebagai upaya meningkatkan kemitraan yang dinamis antarsesama guru, dengan orang tua maupun masyarakat, untuk memperbaiki efektivitas sekolah dan memberikan kontribusi bagi masyarakat serta untuk mendapatkan dukungan sumber daya manusia maupun dana. Pola pengembangan hubungan kerja sama dibangun dengan menjaga hubungan yang baik secara personal maupun social, membuat dan menentukan perencanaan program-program yang relevan serta mengimplementasikannya sesuai visi dan misi sekolah.

Pengembangan hubungan kerja sama yang dilakukan kepala TK Kanisius Wirobrajan merupakan misi dari kepala TK sehingga dalam berbagai kegiatan dan program sekolah melibatkan guru, karyawan dan orang tua secara sistematis mulai dari perencanaan, pelaksanaan dan monitoring. Pengembangan hubungan ini bertujuan menjalankan visi dan misi sekolah, sebagai kekuatan dalam menghimpun dan menggerakkan anggota serta untuk memperoleh berbagai dukungan sumber daya manusia, dana serta dukungan informasi berbagai pihak terkait, dalam rangka mencapai tujuan secara optimal.

Untuk memperkuat kepemimpinan kepala TK pada aspek pengarahan, pendelegasian, pemberian keputusan dan pe- ngembangan hubungan kerja sama perlu dikembangkan manajemen kepemimpinan yang bersifat inklusif. Hasil riset Karana (2016, p. 75) merekomendasikan bahwa sekolah sebagai penyelenggara pendidikan inklusif dan kepala sekolah sebagai pelaksana kepemimpinan berperan dalam: (1) meningkatkan, mengembangkan wawasan, dan pengetahuan pendidik dan tenaga kependidikan; (2) sekolah sebagai penyelenggara pendidikan inklusif diharapkan dapat mengoptimalisasi pemenuhan dan pengelolaan sarana dan prasarana; (3) sekolah sebagai penyelenggara pendidikan inklusif diharapkan dapat memenuhi kebutuhan anggaran/pembiayaan pengembangan program pendidikan inklusif. Jelas bahwa peran kepemimpinan kepala TK dalam menjalankan keempat fungsi tersebut semestinya didukung oleh kemampuan manajerial sekolah yang bersifat inklusif. Tujuan dari penguatan manajerial sekolah yang bersifat inklusif adalah memperkuat perilaku kepemimpinan supportif, direktif dan partisipatif.

Berdasarkan empat aspek yang ditemukan pada kepemimpinan kepala TK Kanisius Demangan Baru Yogyakarta, maka perilaku yang diperankan lebih berorientasi pada perilaku supporting, yakni ditemukan karyawan telah memiliki kemandirian dan kemampuan untuk melaksanakan tugas pekerjaan serta pekerjaan yang telah tertata dengan baik (Wuradji, 2008, p. 37). Disini pemimpin menerapkan perilaku tugas rendah dan perilaku hubungan rendah karena guru dan karyawan sudah senior serta kerja sama dengan orang tua sudah berjalan dengan baik, sehingga guru dan karyawan hanya perlu disupport untuk mendukung peran dan pengalaman serta skill mereka. Kepemimpinan kepala TK Kanisius Kotabaru Yogyakarta, maka perilaku yang diperankan lebih berorientasi pada perilaku direktif, yang ditemukan bahwa pemimpin mene-rapkan tugas pada level tinggi dan perilaku hubungan pada level rendah, pemimpin menentukan tentang apa, kapan, bagaimana dan bagaimana target yang harus dicapai serta menjelaskan tugas yang dilakukan sampai pada 
tingkat operasional (Wuradji, 2008, p. 35). Kepemimpinan kepala TK Kanisius Wirobrajan Yogyakarta, maka perilaku yang diperankan lebih berorientasi pada perilaku partisipatif, yang ditemukan bahwa pemimpin menggunakan partisipasi anggota sebagai alat komunikasi, bersama anggota melakukan control terhadap kemajuan prestasi sekolah, bersama merumuskan kebijakan organisasi dan garis-garis besar pengimplementasian tugas yang akan dilakukan (Wuradji, 2008, p. 38).

Berdasarkan perilaku yang ditemukan pada masing-masing kepala TK Kanisius Yogyakarta tersebut, maka model kepemimpinan kepala TK Kanisius lebih berorientasi pada model kepemimpinan Instruksional, hal ini berdasarkan pengarahan, pengambilan keputusan, pendelegasian dan pengembangan hubungan yang ditemukan sebagai pemimpin instruksional memiliki pengaruh langsung terhadap struktur intern sekolah, organisasi instruksional, instruksional praktek dan iklim sekolah atau menekankan pada peningkatan pengajaran dan pembelajaran di sekolah. Hal ini menandakan bahwa kepemimpinan kepala sekolah bukanlah semata-mata sebuah atribut pribadi melainkan sederet aktivitas dan tindakan-tindakan yang berpola berdasarkan kapasitas pengetahuan, keterampilan, dan kebiasaan-kebiasan yang secara objektif diajarkan, dan dipelajari secara terus menerus sehingga membangun sebuah karakter leadership yang efektif dan berdaya manfaat bagi perbaikan mutu dan pelayanan di sekolah. Kepala TK Wirobrajan mengembangkan kapasitas kepemimpinan simbolik dan kultural dengan memodelkan nilai-nilai dan perilaku-perilaku penting ke dalam lingkungan pembelajaran di sekolah dan masyarakat, termasuk komitmennya untuk menciptakan serta mempertahankan komunitas pembelajaran yang profesional dan efektifm (OECD, 2008a, p.44; OECD, 2008b, p. 91). Hal ini terlihat dalam berbagai agenda kedinasan yang terprogram dan kerja sama dengan pemerintah dan masyarakat di sekitar sekolah melalui program unggulan sekolah seperti pementasan seni budaya untuk me- melihara nilai-nilai kearifan lokal budaya Jawa.

Dari uraian-uraian di atas terlihat bahwa hal yang membedakan dari masingmasing kepemimpinan di ketiga sekolah TK Kanisius Yogyakarta adalah kemampuan individual kepala sekolah dalam meng-upgrade kapasitas pengetahuan, keterampilan dan kebiasaan atau praktik kepemimpinannya dalam tugas dalam layanan pendidikan sesuai domain dan kapasitas kepemimpinannya. Semakin mereka mampu menjembatani antara masalah dan kebutuhan belajar dengan strategi dan visi bekerja yang lebih baik kepemimpinan mereka menjadi semakin efektif. Pemahaman yang baik terhadap kapasitas kemampuan dan skill bawahan atau rekan kerja guru membuat kepemimpinannya memiliki daya pengaruh.

Setiap model kepemimpinan memiliki kelebihan dan keterbatasannya sehingga yang paling menentukan adalah strategi kepala sekolah dalam memahami masalah dan memberi solusi secara cepat dengan gaya leadership-nya masing-masing. Karakter kepemimpinan yang baik ditentukan juga oleh daya dukung internal dan eksternal serta upaya pengembangan kualitas diri kepala sekolah sendiri secara kontinum dengan menginvestasikan waktu dan pengembangan diri secara berkelanjudan melalui program-program upgrading guru dan kepala sekolah seperti latihan kepemimpinan, peningkatan kapasitas profesionalisme diri melalui pengembangan keprofesian berkelanjutan (sustainable leadership), memperluas net working dengan memberdayakan forum asosiasi kepala sekolah (leading learning community) dengan memperkuat jaringan kerja sama yang sudah ada dan membuka jaringan kerja sama di level nasional dan internasional (OECD, 2008a, pp. 42-75). Semua upaya ini penting untuk terus menjaga spirit dan motivasi kepemimpinan dan menjadikan kepemimpinan profesional sebagai budaya mutu di sekolah.

\section{Simpulan}

Simpulan hasil penelitian dari kepemimpinan kepala TK Kanisius Yogya- 
karta sebagai berikut: Pengarahan dilakukan langsung dan tidak langsung, melalui rapat, diskusi, dan briefing morning, mengenai tugas pokok, tugas khusus dan tugas penunjang. Hal ini dilakukan sebagai upaya tertib administrasi dan merencanakan pelaksanaan program sekolah, yang bertujuan meningkatkan motivasi, meningkatkan kinerja guru sehingga bermanfaat bagi sekolah dan dirinya sendiri, serta sebagai upaya mengelola sumber daya untuk pencapaian visi dan misi sekolah.Keputusan diberikan untuk pembagian tugas pokok, tugas khusus dan mengenai persoalan yang terjadi. Proses pengambilan keputusan melalui musyawarah, koordinasi pihak yayasan dan identifikasi masalah berdasarkan data serta bersifat formal dan informal, yang bertujuan memecahkan persoalan, mengembalikan prestasi sekolah, meningkatkan kinerja guru dan karyawan, membuat keputusan final dalam mengatur, mengelola, mengendalikan kelompok serta meningkatkan produktivitas sekolah dalam pencapaian tujuan.Pendelegasian dilakukan mengenai tugas pokok, tugas khusus dan tugas penunjang, yang didasarkan pada kemampuan, peran bawahan, target waktu, jenis tugas, dan target pencapaian. Hal ini dilakukan sebagai sarana untuk memberikan tanggung jawab, untuk melakukan penilaian, meningkatkan keyakinan dan inisiatif guru serta karyawan, untuk mengembangkan kreativitas, sebagai kekuatan untuk memperluas keterampilan dan kemahiran guru dan karyawan dalam menjalankan peranannya di sekolah. Kerja sama internal sekolah dibangun melalui tugas pokok, tugas khusus dan penunjang serta menjaga hubungan yang baik secara personal. Kerja sama dengan orang tua, dan masyarakat melalui kegiatan penunjang dan hubungan sosial yang baik, dalam rangka meningkatkan kemitraan yang dinamis, memperbaiki efektivitas sekolah, memberikan kontribusi bagi masyarakat, untuk mendapatkan dukungan sumber daya manusia dan dana, sebagai kekuatan dalam mencerdaskan serta membentuk karakter anak didik kearah tercapainya tujuan pendidikan, sosial, budaya dan untuk karier guru. Berdasarkan empat aspek yang ditemukan pada kepemimpinan kepala TK Kanisius, maka kepala TK Kanisius Demangan Baru Yogyakarta berorientasi pada perilaku supporting, kepemimpinan kepala TK Kanisius Kotabaru Yogyakarta berorientasi pada perilaku direktif, kepemimpinan kepala TK Kanisius Wirobrajan Yogyakarta berorientasi pada perilaku partisipatif. Dari perilaku yang ditemukan pada setiap kepala TK Kanisius Yogyakarta tersebut, maka model kepemimpinan kepala TK Kanisius lebih berorientasi pada model kepemimpinan Instruksional.

Adapun beberapa saran yang diusulkan dari hasil penelitian ini adalah sebagai berikut: Model kepemimpin kepala TK juga sangat ditentukan oleh perilaku pemimpin dan pendekatan yang dilakukannya. Seorang pemimpin seperti kepala TK harus memiliki keterampilan memimpin yang baik (skill leadership). Kepala sekolah TK perlu diberikan pelatihan dan kursus school leadership seperti menaikan kapasitas teknis, kapasitas edukatif, kapasitas kultural dan simbolis. Beberapa kemampuan leadership ini dapat dilakukan dengan memberdayakan hal-hal seperti yang direkomendasi oleh (OECD, 2008, p. 46) yaitu: (1) kemampuan menyelaraskan instruksi dengan standar nasional pendidikan, (2) menetapkan tujuan sekolah untuk kinerja guru dan siswa, mengukur kemajuan terhadap tujuan dan menyesuaikan programprogram sekolah untuk meningkatkan kinerja secara individual dan kolektif (3) Perlu adanya keputusan dan kebijaksanaan atas manajemen sumber daya manusia dan keuangan serta penggunaan sumber daya strategis sekolah dan yayasan untuk tujuan pedagogis. (4) Memberdayakan keterlibatan kepemimpinan di luar sekolah, dalam kemitraan dengan sekolah lain, komunitas, lembaga sosial, universitas melalui bantuan timbal balik sehingga menciptakan kohesi yang lebih besar di antara semua pihak yang peduli dengan keberhasilan siswa dan peningkatan mutu pendidikan.

Setiap model kepemimpinan memiliki kelebihan dan kelemahannya masingmasing. Kepemimpinan instruksional perlu 
diperluas dengan model kepemimpinan lain seperti kepemimpinan transfromasional untuk menjembatani dan mengintegrasikan nilai-nilai dasar Kanisius dengan dinamika perubahan dan tuntutan dunia pendidikan yang makin kompetitif saat ini. Perlu juga adanya perluasan dan pengembangan beberapa kapasitas kepemimpinan kepala TK pada aspek kerja sama, baik ditingkat lokal, nasional dan internasional untuk memperkuat daya tarik dan menjadikan sekolah sebagai magnet bagi siswa, orang tua dan warga masyarakat.

Upaya trasnformasi nilai-nilai Kanisius harus terus dilakukan agar kekayaan nilai-nilai Kanisius tidak hanya mengakar pada mayoritas siswa yang beragama Katolik tetapi bisa meluas menjadi garam dan terang bagi dunia sesuai visi dan misi Kristiani Gereja Katolik dalam dunia pendidikan saat ini (Mat 5:15-16). Proses transformasi itu harus dimulai dari sang pemimpin yang hadir sebagai sosok sang gembala dan sang guru seperti Yesus yang menyambut dan memberkati anak-anak dengan gembira dan penuh kebijaksanaan (Mat 18:1-4;19:13-15, Mrk 9:33-37;10:13-16). Guru dan karyawan harus mampu mendukung kepala sekolah dalam menjalankan perannya sebagai pemimpin, diharapkan saling bersinergi dan konsisten dalam menjalankan visi dan misi untuk mencapai tujuan dan esensi pendidikan Katolik yang mengintegrasikan antara moralitas dan kecerdasan (Mardiatmadja, 2017, p. 41). Mampu membagun iklim sekolah sesuai nilai-nilai yang diyakini dalam menjalankan tugas dan tanggung jawab di sekolah. Penelitian selanjutnya diharapkan memperluas ruang lingkup penelitian dan informannya, sehingga hasil penelitiannya lebih akurat serta menjadikan pedoman untuk melakukan penelitian yang relevan dengan kepemimpinan kepala sekolah.

\section{Daftar Pustaka}

Barr, Y. J., \& Duke, K. (2004). What do we know about teacher leadership? findings from two decades of scholarship. University of Minnesota, http://rer.aera.net, 74, 255-316.

Blanchard, K. (2007). Leading at a higher level. America: Pearson Prentice Hall.

Baxter, P., \& Jack, S. (2008). Qualitative case study methodology: Study design and implementation for novice researchers. The Qualitative Report, 13(4), 554-559. Retrieved from http://nsuworks.nova.edu/tqr

Bogdan, R. C., \& Biklen, K. S. (1982). Qualitative research for education: An introduction to theory and methods. America: Allyn and Bacon, Inc.

Davies, B. (2006). Leading the strategically focused school: Success \& sustainability. Thousand Oaks California: Sage Publications.

Giri, N.V., \& Kumar, B. P. (2007). Impact of organizational climate on job satisfaction and job performance. Psychological Studies National Academy of Psychology (NAOP) Springer, 52, 131133.

Hoy, W.K,. \& Miskel, C.G. (2007). Educational administration:Theory, research and practice. New York America: Mc Graw Hill.

Karana, D. P. (2016). Implementasi manajemen pendidikan inklusif di sd negeri gadingan wates dan mi ma'arif pangerharjo samigaluh. Jurnal Akuntabilitas Manajemen Pendidikan, 4(1), 63-76. Retrieved from http://journal.uny.ac.id/index.php/j amp/article/view/8192

Kemendiknas. (2010). Peraturan Menteri Pendidikan Nasioanal Nomor 28 Tahun 2010, tentang Penugasan Guru sebagai Kepala Sekolah/Madrasah

Leithwood, K., Harris, A., \& Hopkins. D. (2008). Seven strong claims about successful school leadership. School Leadership \& Management, 28, 27-42.

Mardiatmadja, B. S. (2017). Arah dan ranah pendidikan. Dalam Paul Suparno, dkk. Lembaga pendidikan katolik. Yogyakarta: PT Kanisius. 
Maryono. (1993). Yayasan kanisius setelah 75 tahun. Yogyakarta: Percetakan Kanisius.

OECD, (2008a). Improving school leadership: Police and practice. (H. M. Beatriz Pont, Deborah Nusche, Ed.) (Vol. 1). Paris: Clearance Center (CCC). Retrieved from

http://www.oecd.org/education/sch ool/improvingschoolleadershiphome.htm

OECD. (2008b). Improving school leadership: Case studies on system leadership. (D. H. Beatriz Pont, Deborah Nusche, Ed.) (Vol. 2). Paris: Clearance Center (CCC). Retrieved from http://www.oecd.org/education/sch ool/44375122.pdf

Pearce, K. (2015). Creting leadership through the teacher learning and leadership program. The educational Forum, 79, 46-52.

Tobias, J., Wales, J., Syamsulhakim, E., \& Suharti. (2014). Toward better education quality indonesia's promising path-case study education. Development Progres.org.

Wahjosumidjo. (2013). Kepemimpinan kepala sekolah: Tinjauan teoretik dan permasalahannya. Jakarta: PT. Raja Grafindo Persada.

Wuradji, M.S. (2008). The education leadership:Kepemimpinan transformatif. Yogyakarta: Gama Media.

Yin, R. K. (2009). Case study research: Design and methods (5th ed.). California: Sage Publications, Inc.

Yin, R.K. (2014). Studi kasus: Desain E metode (Terjemahan M.Djauzi Mudzakir). Depok: PT. Raja Grafindo Persada.Edisi asli diterbitkan tahun 1987 oleh Massachusetts Institute of Technology. USA).

Zbar, V., Marshall, G., \& Power, P. (2007). Better schools-better teachers-better results. Australia: Acer Press. 